\title{
Are Enterprise System Benefits the Same for Universities as they are for Supermarkets?
}

\author{
Leonard, Jenny; Zinner Henriksen, Helle
}

Document Version

Final published version

Publication date:

2011

License

CC BY-NC-ND

Citation for published version (APA):

Leonard, J., \& Zinner Henriksen, H. (2011). Are Enterprise System Benefits the Same for Universities as they are for Supermarkets?. Paper presented at The 5th International Conference on Research and Practical Issues of Enterprise Information Systems 2011, Aalborg, Denmark.

Link to publication in CBS Research Portal

\footnotetext{
General rights

Copyright and moral rights for the publications made accessible in the public portal are retained by the authors and/or other copyright owners and it is a condition of accessing publications that users recognise and abide by the legal requirements associated with these rights.

\section{Take down policy}

If you believe that this document breaches copyright please contact us (research.lib@cbs.dk) providing details, and we will remove access to the work immediately and investigate your claim.
} 


\title{
Are Enterprise System benefits the same for Universities as they are for supermarkets?
}

\author{
Jenny Leonard ${ }^{1}$, Helle Zinner Henriksen ${ }^{2}$ \\ ${ }^{1}$ University of Sydney Business School \\ ${ }^{2}$ Copenhagen Business School
}

\begin{abstract}
Enterprise Systems have become the default support systems for business processes in commercial organisations. Their promise of increased efficiency and effectiveness fits well with profit-based strategic objectives, and can be linked directly to customer choice. The last fifteen years have seen extensive implementation of Enterprise Systems in the University sector. While efficiency and effectiveness may be important in this sector, they are not linked directly to customer choice - the concept of a customer is complex, and choices may include many influences which are unaffected by administrative processes. Using one Australian and one Danish University as examples, an analysis of the benefits from using Enterprise Systems in Universities and in supermarkets is undertaken. There are some differences in the nature of those benefits. More importantly, differences in links between those benefits and the effect on customer choice are pronounced, with significant impacts for research and practical implications of Enterprise Systems.
\end{abstract}

Keywords Enterprise Systems, University Enterprise Systems, Business Process Modelling

\section{Introduction}

Most commercial organisations of any size are supported by Enterprise Systems. Benefits from such systems come from integration, process optimisation, and improved access to information [1], although such benefits do not always eventuate [2-10]. Customers must benefit [11, 12] in order to support strategies for long term survival in the market place [13-17]. Supermarkets represent an illustrative example: they utilize support systems for business activities throughout the supply chain - when a customer checks goods out at the POS terminal, for example, data is submitted to the supplier to make sure that shelves remain stacked.

Universities also, increasingly use Enterprise Systems [18-23]. They undertake a number of similar activities to supermarkets. For example, Universities enrol students, educate them, test them, and finally graduate them by issuing a certificate confirming that they have fulfilled the requirements of a particular study. Or, to put it in a more simplistic manner, Universities have a number of "goods" on the "shelves" from which their customers (the students) select, in ways which are, fundamentally similar to supermarkets. There are also plenty of customers - there are typically more applicants than seats at Universities. There is plenty of supply Universities offer a great variety of subjects and courses providing an attractive mix to most students. There are many "producers" - professors, lecturers, PhD students, capable of offering courses and electives.

The question arises: do Universities attain the same benefits from Enterprise Systems as do supermarkets? The budget to implement an Enterprise System can be of the order of millions of Euros, so the question is critical. This paper compares the benefits of using Enterprise Systems in supermarkets and Universities respectively, and finds similarities. However, business benefits must be directly related to customer choice [11, 12], and here, there is a fundamental difference. For supermarkets, almost all factors affecting customer choice are affected by Enterprise System-related benefits [24]. For Universities, by contrast, a much smaller proportion of customer choice factors are influenced by such benefits. A University's "customer" is a split concept - students choose, and in some cases pay for their studies, but Governments also pay, and to that extent can also be considered a customer. Student choices are rarely related to Enterprise System benefits [25]. Government "choices", by contrast are related, as Government funding is based directly on student numbers. This is true for both Governments investigated in the study: Denmark and Australia.

Several research and practical implications arise from this study, including appropriate Enterprise System design for Universities, investment decisions for University Enterprise Systems, and project management issues. 


\section{Literature Review}

The use of Enterprise systems has become prevalent within the commercial sector. The proposed benefits of such systems derive from the effectiveness and efficiency that they can provide, because of their ability to integrate data and standardise processes $[5,10]$. There is controversy regarding whether these benefits are achieved in practice. It has been argued that such levels of integration are impossible to achieve in complex organisations, which will always 'drift' from their original, planned intentions [3, 4, 8, 9]. Enterprise System implementations may influence human actors to ensure that their organisations appear more integrated [6], homogeneous [9], or controlled [2]. Others have argued that Enterprise System benefits are achieved, but after a delay [7]. Nevertheless, a growing body of literature suggests that Enterprise Systems are now experiencing a "second wave", in which the many of the problems from "first wave" implementations have been resolved [1, 26]. A recent model of organisational benefits suggests that senior management perceive these as arising from integration, process optimisation, and improved access to information. The extent to which such benefits can be achieved depends on the functional fit of the system, and the ability to overcome organisational inertia [1].

Much of the Enterprise Systems literature is based largely around private organisations, motivated by profit. Such organisations base their strategies on their position in the marketplace [27] and the resource base on which they can draw to retain their strategic advantage [13-15, 28]. They define a value proposition, based on the way in which they deliver benefits to the customer via the value chain [16], or, increasingly, via the value network of which they are a part [29]. They place themselves in the market, based on one, or a mix of three specific strategies. The first of these is operational excellence[17], or cost leadership [16, 30] where they deliver products at lowest cost and in the most timely manner. Such a strategy is well supported by the Enterprise System benefits of process optimisation and integration, and helped by allowing timely managerial decision-making via improved access to information [1]. The second strategy is product leadership[17], or differentiation[16, 30], offering customers the best product in the industry. Here, Enterprise Systems can be of benefit in providing the improved access to information required to innovate and improve. With caution, process optimisation can also be of benefit, although it is important to ensure that the organisation can differentiate its product from others. The third strategy is customer intimacy[17], or focus[16, 30], where a particular niche market is exploited to satisfy the needs of specific customers . Here, the improved access to information afforded by Enterprise Systems together with optimised processes and integration allow the organisation has "one view" of the customer.

However, there are specific reasons why the strategic positions discussed may not apply in Universities. An extensive study of strategic activity at Universities, found that they "typically have a fragmented professional workforce, pursuing divergent goals and interests with little concern for strategy as a collective organizational activity....Universities pursue multiple, contradictory activities that create tensions between professional and managerial interests. This increases the distributed nature of activity and further challenges the strategizing resources of top managers.” [31]

Despite the complexity of their strategies, Universities have a long history of attempts at standardisation and sharing of administrative systems. In the 1990s, several countries instigated national programmes to develop shared Enterprise Systems. These include the Management and Administrative Computing (MAC) initiative in the UK, which began in 1988 [32, 33], and CASMAC, in Australia, which was modelled on the MAC initiative, and collapsed in the late 1990s [32, 34-36]. During the same period Sweden implemented LADOK, The Gigue initiative was used in France, Holland had a series of initiatives, including SUAA, SURG, and SUNCOO. America, by contrast, had no such initiative [37]. Few of these initiatives survive today, with the notable exception of LADOK, which provides a student administrative system from elementary school through to University [38]. The early $21^{\text {st }}$ century, spurred by Y2K problems, saw many Universities implementing Enterprise Systems [19, 22]. A minority chose, at this late stage, to implement in-house systems. Student administration systems include Oracle/Peoplesoft, widely used in the USA, and implemented in about a third of Australian Universities [20], SITS/Tribal which is used in 60\% of UK Universities [21], and Technology One [23] and Callista [18], which are, respectively, each used in about a third of Australian Universities. A Danish technology provider (UNI-C) introduced the STADS system, which initially suffered from large budget overruns and delays which complicated the uptake. Recently, all Danish Universities have decided to implement the student administrative system, thus unifying student administration across the eight Danish Universities. Student administrative systems are often sold as part of an Enterprise Suite including HR, Finance, Facilities Management and Library Systems. 


\section{Research question and method}

The question arises: why are Enterprise Systems prevalent in Universities? How do they provide benefits, given that such systems were designed for corporate, private use and Universities pursue "multiple, contradictory activities that create tensions between professional and managerial interests”[31]? This leads to a general research question and two more specific questions:-

How do Universities benefit from Enterprise Systems?

- $\quad$ Are Enterprise System benefits the same for Universities as they are for supermarkets?

- What part do those benefits play in influencing customer choice.

This paper explores the main administrative processes in supermarkets and in Universities, identifies the benefits that can be gained from using Enterprise Systems for those processes, and then compares those benefits with the ones influencing customer choice. A key audit publication has identified possible parallels between audit cycles in the commercial sector and those in University education. It suggest that the revenue cycle (also known as "order to cash") could, at a University, be referred to as "enrolment to cash", and that the inventory cycle has a parallel in the University sector of "admission-to-graduation” [39] p57. Figure 1 illustrates the parallels between the two organisations.

Figure 1: Parallels between supermarkets and Universities

The supermarket scenario
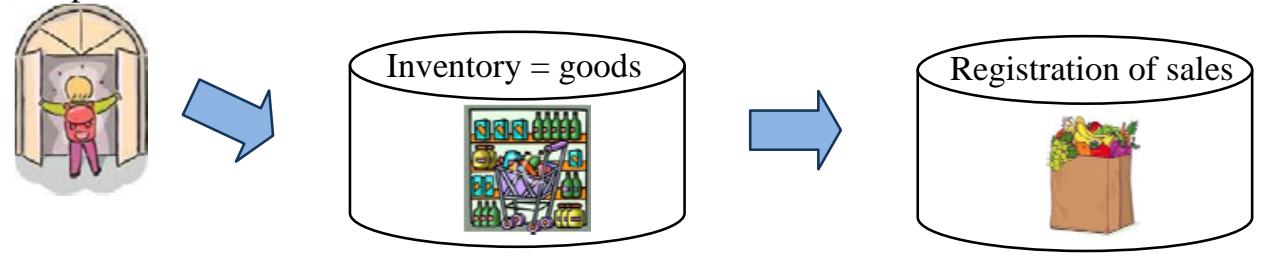

The university scenario
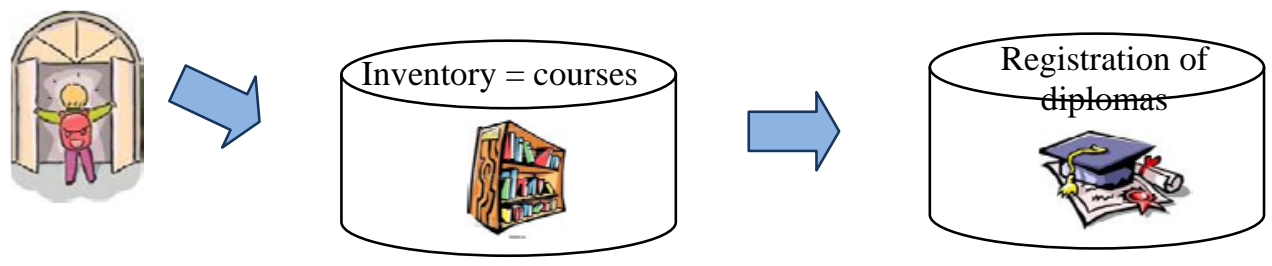

The paper therefore describes the relationship between factors affecting customer choices of supermarkets [24] and the benefits obtained from Enterprise Systems in its revenue and inventory cycles. It then compares this relationship to influences on "customer" choices in the University sector [25] and its (parallels to) revenue and inventory cycles. The investigation is limited to activites related to a University's teaching activities - research activities are not discussed. Because University strategy is likely to be linked to national strategies, the processes at two Universities are examined - one in Australia and one in Denmark. These countries have significantly different strategies for tertiary education. 


\section{Background of the two Universities}

Both Universities in this study are in major municipal centres and have a relatively long history. For the purposes of this study, investigation is limited to the Business Schools in each institution. The Danish University is nearly 100 years old* and the Australian University is 160 years old**. Both are highly ranked for research relative to other Universities in their respective countries. In both Denmark and Australia, domestic school-leavers apply to a central system (in the Australian case, this replaced a state-based system two years ago [40]). They rank their preferences and are offered places at University based on those preferences together with their school qualifications. In the case of the Danish business school, the majority of students are domestic. 10\% of places are reserved for students admitted outside the system who have, for example, work experience to compensate for qualifications. While other European Union citizens can enrol, the number who do so is limited by the fact that most degrees are taught in Danish, and there are very few non-European Union citizens enrolled. By contrast, the Australian University has a large international student body, representing 134 countries. Of the 49,000 students enrolled in 2010, 10,800 were international. For the business school the figures were 8,000 students of which 4,000 were international**. These figures should be seen in the context of tertiary education in Australia as a whole - 630,000 students were enrolled at Australian Universities in 2009[41]. **

In Denmark, students do not pay fees, and, indeed, are paid to go to University provided they obtain enough credits (30) to indicate that they are studying full time. By contrast, all Australian students pay fees. Domestic students pay fees which are supported, to some extent, by the central government (Commonwealth). They are able to make use of a government sponsored loan system at preferential rates, which does not have to be paid until they finish their studies and are earning reasonable salaries. For 2011, for example, domestic undergraduate students studying for a Bachelor of Commerce would be charged an annual fee of around \$AUD6,800. ** (approx EUR5,000) Since 1985, international students have been allowed to enrol at Australian institutions "if they met the entry requirements and paid the full cost of their course" [41]. An international undergraduate paying full fees would be charged an annual fee of around \$AUD32,600 (approx EUR24,000).

Both Danish and Australian Universities receive Government finance. Danish Universities operate under the Universities Act, and are funded based on the number of students who pass their exams; this is known as the "taximeter" system[42]. The Australian National University and the Australian Maritime College are established under Commonwealth (national) legislation. All other statutory higher education institutions are established under State or Territory legislation. Since 2002, operating resources for teaching and learning have been provided as a single base operating grant for a specified number of Commonwealth-supported student places within the context of an Educational Profile. Universities who over-enrol have been "capped” at 5\% in terms of the grant received in respect of the extra students. Resources have been allocated as a rolling triennium [43]. Resource levels are informed by yearly reports on student numbers, including original enrolments and retention rates. This system is currently changing: since the 2009-10 budget Australia has been moving to a demanddriven system, where the Government will "provide Commonwealth supported places for all domestic undergraduates accepted into an eligible, accredited higher education course with a recognised public higher education provider.”: by 2012 the cap will be removed, as will the concept of the base operating grant. [44] 


\section{Supermarket Processes, Enterprise System benefits and links to customer choice}

Table 1 below indicates the main processes in the supermarket revenue cycle (“order to cash”), and inventory cycle, together with the appropriate Enterprise Systems benefits.

Table 1. Supermarket Revenue and Inventory Cycle and Enterprise systems.

\begin{tabular}{|c|c|}
\hline Activity & Organisational benefits [1] \\
\hline \multicolumn{2}{|l|}{ Revenue cycle } \\
\hline $\begin{array}{l}\text { Customer chooses } \\
\text { weekly shopping }\end{array}$ & $\begin{array}{l}\text { - Improved integration means that the goods customers require are available on the } \\
\text { shelves, and that customer enquiries can easily be addressed. } \\
\text { Improved access to information: ensures that customers can find the goods they } \\
\text { require and can also be encouraged to spend more, by, for example, analysing } \\
\text { products that customers buy together and placing them appropriately, and } \\
\text { understanding the best marketing needs. }\end{array}$ \\
\hline $\begin{array}{l}\text { Store minimises } \\
\text { shoplifting }\end{array}$ & - Improved access to information: improves detection and prevention strategies \\
\hline $\begin{array}{l}\text { Customer pays for } \\
\text { shopping }\end{array}$ & $\begin{array}{l}\text { Integration means that inventory can be updated as soon as customer pays, } \\
\text { leading to improvements in the inventory cycle } \\
\text { Process optimisation means that costs of accepting payment are minimised, and } \\
\text { the customers' experience is improved } \\
\text { - Improved access to information means that customer spending can be analysed to } \\
\text { improve the inventory cycle }\end{array}$ \\
\hline \multicolumn{2}{|l|}{ Inventory cycle } \\
\hline $\begin{array}{l}\text { Inventory levels } \\
\text { checked }\end{array}$ & $\begin{array}{l}\text { - Integration means that inventory levels are automatically changed as customer } \\
\text { purchases are made, hence lowering costs. } \\
\text { - } \quad \text { Process optimisation means that restocking algorithms can be automated }\end{array}$ \\
\hline $\begin{array}{l}\text { Appropriate purchase } \\
\text { orders to vendors }\end{array}$ & $\begin{array}{l}\text { Process optimisation: Purchase orders and other documents to vendors can be } \\
\text { automated } \\
\text { - Improved access to information means that purchasers can make better strategic } \\
\text { decisions }\end{array}$ \\
\hline $\begin{array}{l}\text { Goods received and } \\
\text { invoices paid }\end{array}$ & $\begin{array}{l}\text { - Integration: ensures that payment is only made when goods are received, and that } \\
\text { this can be automatically checked against the purchase order. } \\
\text { Process optimisation ensures that payment schedules are based on minimising } \\
\text { costs, within the constraints of vendor relationship management. } \\
\text { - Improved access to information means that records are kept of any poor quality } \\
\text { purchases, wrong deliveries etc from vendors, and this can be used in strategic } \\
\text { purchasing decisions }\end{array}$ \\
\hline
\end{tabular}

While Table 1 indicates several ways in which Enterprise Systems can provide benefits, these have not been mapped against the full picture of customer preferences. To do that mapping, Table 2 below reproduces the findings of a recent survey of supermarket shoppers in the UK regarding the influences on their choice of store for main grocery shopping [24], and any direct or indirect relationship with Enterprise Systems Benefits 
Table 2 Factors affecting choice of store for main grocery shopping.[24] (App) p 31

\begin{tabular}{|c|c|c|c|}
\hline Factor & $\begin{array}{c}\text { Import } \\
\text {-ant }\end{array}$ & Main & Effect of ES benefit \\
\hline $\begin{array}{l}\text { Ability to get most of the weekly shopping done } \\
\text { under one roof }\end{array}$ & $69 \%$ & $43 \%$ & $\begin{array}{l}\text { Direct: improved access to } \\
\text { information ensures supermarket has } \\
\text { clear picture of all customer needs }\end{array}$ \\
\hline Price charged for groceries & $58 \%$ & $18 \%$ & $\begin{array}{l}\text { Direct: process optimisation ensures } \\
\text { costs are minimised }\end{array}$ \\
\hline Within easy and convenient reach of home & $55 \%$ & $16 \%$ & \\
\hline A large range of grocery products to choose from & $45 \%$ & $6 \%$ & $\begin{array}{l}\text { Direct: integration of supply chain } \\
\text { ensures wide range of stock available }\end{array}$ \\
\hline Availability of sufficient car-parking space & $38 \%$ & $6 \%$ & \\
\hline Products I want always in stock & $36 \%$ & $4 \%$ & $\begin{array}{l}\text { Direct: integration of supply chain } \\
\text { ensures constant stock levels. }\end{array}$ \\
\hline Flexible opening hours & $36 \%$ & $4 \%$ & $\begin{array}{l}\text { Indirect: process automation may } \\
\text { help to ensure that opening hours ca } \\
\text { be flexible }\end{array}$ \\
\hline Extra facilities such as petrol station, coffee shop & $12 \%$ & $0 \%$ & \\
\hline Shopping experience/style image of store & $6 \%$ & $1 \%$ & $\begin{array}{l}\text { Indirect: improved access to } \\
\text { information ensures understanding of } \\
\text { customers' image/style aspirations. }\end{array}$ \\
\hline Proximity to other shops / recreational facilities & $5 \%$ & $0 \%$ & \\
\hline
\end{tabular}

\section{University Processes, Enterprise System benefits and links to customer choice}

Table 3 describes the main University "Revenue” and "Inventory” Cycles and the Enterprise System benefits associated with them.

Table 3. University "Revenue” and "Inventory” Cycles and Enterprise systems.

\begin{tabular}{|c|c|}
\hline Activity & Organisational benefits [1] \\
\hline \multicolumn{2}{|c|}{ Revenue cycle "enrolment to cash" } \\
\hline $\begin{array}{l}\text { Student enrols in a } \\
\text { degree }\end{array}$ & $\begin{array}{l}\text { - Integration allows student details to be checked, so that they are correct, hence } \\
\text { fulfilling compliance requirements } \\
\text { Process optimisation, for example by allowing students to perform most of their } \\
\text { enrolment processes via the web can save significant costs, and can also improve } \\
\text { the student experience. } \\
\text { Improved access to information enables students to be advised well regarding the } \\
\text { degree they intend to undertake. }\end{array}$ \\
\hline $\begin{array}{l}\text { (Australia only) } \\
\text { Student pays fees } \\
\text { directly, or takes out a } \\
\text { HECS loan }\end{array}$ & $\begin{array}{l}\text { Integration ensures that students are correctly invoiced. } \\
\text { Process optimisation ensures that fees are collected promptly and appropriate } \\
\text { debt collection is in place } \\
\text { Improved access to information ensures that strategies for fee collection are } \\
\text { appropriate }\end{array}$ \\
\hline $\begin{array}{l}\text { University statistics } \\
\text { sent to Government }\end{array}$ & $\begin{array}{l}\text { Improved access to information enables the appropriate reporting returns to } \\
\text { Government, required in order to obtain money, to be made. }\end{array}$ \\
\hline $\begin{array}{l}\text { Government pays } \\
\text { University money } \\
\text { based on statistics }\end{array}$ & $\begin{array}{l}\text { - Depending on the system the Government pays based on the number of students } \\
\text { who pass their exams (Denmark), or the number of students enrolled (Australia). } \\
\text { Money is given as a total sum which the institution then distributes. } \\
\text { It is crucial to a University to be able to register the number of students in a } \\
\text { precise and timely manner in order to receive the sum of money to which it is } \\
\text { entitled within a given fiscal year }\end{array}$ \\
\hline
\end{tabular}




\begin{tabular}{|c|c|}
\hline & $\begin{array}{l}\text { - Reliable data gives University management a more robust foundation for } \\
\text { forecasting the need for teachers for various subjects. This is critical in University } \\
\text { systems where recruitment of academic staff is a long and demanding process. }\end{array}$ \\
\hline \multicolumn{2}{|c|}{ Inventory cycle: "admissions to graduation" } \\
\hline $\begin{array}{l}\text { Student is admitted } \\
\text { based on application }\end{array}$ & $\begin{array}{l}\text { - Improved access to information ensures that the most appropriate students are } \\
\text { admitted. }\end{array}$ \\
\hline $\begin{array}{l}\text { Specific units of study } \\
\text { are provided within } \\
\text { each degree }\end{array}$ & $\begin{array}{l}\text { Integration has the potential to ensure that there is less duplication of offerings, } \\
\text { although in practice this is hard to achieve. In the Australian University degrees } \\
\text { are highly complex, and units of study within them can be proposed by individual } \\
\text { Disciplines and approved centrally. In the Danish University degrees are highly } \\
\text { structured. Units of study are designed within that structure. }\end{array}$ \\
\hline $\begin{array}{l}\text { Academics are } \\
\text { assigned to teach units } \\
\text { of study }\end{array}$ & $\begin{array}{l}\text { - Improved access to information could be used to analyse the load model, but this } \\
\text { is not done by either University, and might not achieve any strategic aim. Both } \\
\text { Universities use a load model based on the number of contact hours expected of } \\
\text { an academic per year. } \\
\text { Improved access to information could also help in the assignment of academics to } \\
\text { units of study, but currently that information is provided on an ad hoc basis in } \\
\text { both Universities. Assignment of academics is the responsibility of the Chairs of } \\
\text { Discipline in the Australian University, who are responsible for all outcomes in } \\
\text { their Discipline, including research. In Copenhagen, a Head of Studies allocates } \\
\text { academics to units of study, and has power within an internal market to do so. }\end{array}$ \\
\hline $\begin{array}{l}\text { Units of study are } \\
\text { timetabled }\end{array}$ & $\begin{array}{l}\text { - Integration can help to ensure that all units of study are correctly timetabled } \\
\text { - } \quad \text { Process optimisation can help minimise clashes }\end{array}$ \\
\hline $\begin{array}{l}\text { Student enrols in } \\
\text { specific units of study } \\
\text { within their degree }\end{array}$ & $\begin{array}{l}\text { Improved access to information can help students with their choices. Students' } \\
\text { enrolment decisions can be based on their degree structure, timetabling } \\
\text { considerations, unit content, and, less frequently, reputation of academic } \\
\text { teaching the unit }\end{array}$ \\
\hline Student is assessed & $\begin{array}{l}\text { - Integration has the potential to improve timing of assessments for students in the } \\
\text { Australian University, who often find they have several units of study due in the } \\
\text { same week from different units of study, but the complexity of the degree } \\
\text { structure means that this might not be feasible. In Denmark, assessments are } \\
\text { governed by the Universities Act. Students can only be assessed once, in a final } \\
\text { examination for each unit of study, so the problem does not arise }\end{array}$ \\
\hline Students are graduated & $\begin{array}{l}\text { - Integration has the potential to ensure that a student's record clearly identifies all } \\
\text { the units of study they have taken, and how those units contribute to their degree. } \\
\text { Improved access to information can help the University to confirm that the } \\
\text { student is eligible to graduate. This would particularly be the case in the } \\
\text { Australian University, where degrees are very complex. }\end{array}$ \\
\hline
\end{tabular}

University strategies are considerably more complex than those of supermarkets. In both Australia and Denmark, government policy dictates much of University teaching-based incomes, based on student numbers (enrolments in Australia, passes in Denmark). Hence, there are incent ives to attract students. But the influences affecting the choice of University are complex. They can be based on University research and teaching reputation, tradition, and possible lifestyle, as well as specific subject choices. For some students wishing to study in Australia, their choice may be influenced by the price of tuition, together with other factors affecting their general cost of living. In Denmark the question of cost of study is irrelevant since students do not pay fees. Moreover, Universities will not always seek to increase student numbers. In Australia, incentives are designed to increase student enrolments, but Universities may have other reasons, implicit in maintaining their reputation, for limiting those numbers. In Denmark, there are some pressures from industry associations and Government to increase student numbers, but some Universities actively seek to limit numbers.

More complexity arises because, using the inventory analogy described earlier, Universities keep two forms of "inventory": the units of study that they teach, and the students they graduate. So, while potential students can be seen as "customers" enrolled and graduated students are part of the University "product”. However, in keeping with our focus of analysis, we are interested in what "customers" of Universities perceive as the 
benefits. Students choose a University, and to that extent are customers. Sometimes they also pay for their education, but sometimes the Government does so, meaning that the Government can also be considered a customer. This section discusses each “customer” in turn.

Regarding student choice of University: a recent Australian survey reviewed the international literature on student choice of University, and then conducted an extensive survey and series of case studies across Australia [25]. Literature from both Europe and Australasia show that student choice cannot be modelled as entirely rational, ie driven by career or economic considerations. Social and individual (structural) factors, leading to educational aspiration and attainment are also important. Therefore hybrid rational/structural models of choice have often been used in a series of studies, "aiming to explain the inter-relationship of choice factors. These studies look at the factors influencing present thinking and current aspirations and beliefs about tertiary study and then examine the impact of a number of personal and social influences, such as socioeconomic background, type of school, geographic location, family expectations and information sources."p4 Student choice is often made as a hierarchy, starting with “'Do I want to go to University at all?'. Later decisions involve a greater number of variables and a greater degree of uncertainty and contradictions, for example, 'I like this course but there are some aspects that do not suit at all' or 'I want to do this course but not at this place or in this faculty'. The European and Australasian literature is summarised: "The overall picture of how students choose institutions and careers is therefore multifaceted. There are a great array of influences on decisionmaking and many factors that could be considered when making choices about an educational pathway. As there is no single unified decision - but rather a series of linked choices some of which subtend others personal, cultural, economic and social factors could impact at any or all points in decision-making” p5.

In Denmark, student loyalty towards his or her University appears to be decreasing because students tend to pick and choose courses and modules from different Universities. There is a steady growth in the share of Danish students going on exchange abroad for one semester and there is similarly a growth in students coming to a Danish University to study for one semester

In Australia, the situation is similar. Almost two thirds of school students intending to go to University make their choice based on a combination of a particular University and a particular course, with most of the remaining third making a choice based on course. Furthermore, more than $40 \%$ of students, if unsuccessful in their first University/course combination, would try for a similar course at another University, compared with about $20 \%$ who would choose a different course at the same University [25]p99.

The choice of Course/University combination is overwhelmingly influenced by personal interests such as “opportunities for an interesting and rewarding career" (96\%), "suits talents and abilities" (93\%), and interest in exploring area of knowledge” (93\%), career/economic considerations such as "confidence in meeting demands of the course" (90\%), and "Employment opportunities for graduates in this area of study" (88\%). Other key influences on choice include "looks like a fun subject to study" (80\%), and advice from teachers (51\%). Costs are also considered by a sizeable minority of students: HECS fees (39\%) and length of course (41\%) p114. 38\% of applicants chose as their first preference research-intensive universities, $19 \%$ chose technology universities, 33\% chose metropolitan Universities, 9\% regional and 1\% other p119.

While recognising that Course/University combination is important, it can also be noted that $75 \%$ of students had a particular university in mind, 23\% had a couple of universities in mind, and $2 \%$ had no idea. Hence, the potential influences regarding choice of University are important. Table 4 reproduces the potential influences on student choice of University in Australia, and compares those with the benefits from Enterprise Systems. 
Table 4 Potential influences of student choice of University [25] p130, and the effect of ES benefits

\begin{tabular}{|c|c|c|}
\hline Potential influence & Level & Effect of ES benefit \\
\hline Wish to do a particular course offered by the University & $91 \%$ & $\begin{array}{l}\text { Indirect: Improved access to information: } \\
\text { details of courses for students; } \\
\text { management information for planning }\end{array}$ \\
\hline Quality of the teaching & $94 \%$ & \\
\hline International character of the University & $46 \%$ & \\
\hline Level of IT usage in teaching & $40 \%$ & \\
\hline $\begin{array}{l}\text { Lower entrance requirements compared to other } \\
\text { Universities }\end{array}$ & $36 \%$ & \\
\hline Reputation of the University with potential employees & $80 \%$ & \\
\hline $\begin{array}{l}\text { Graduates from the University are more likely to find a } \\
\text { job than those who have done a similar degree at some } \\
\text { other University }\end{array}$ & $66 \%$ & $\begin{array}{l}\text { Indirect: Improved access to information } \\
\text { employment rates of alumni }\end{array}$ \\
\hline Prestige of the University & $60 \%$ & \\
\hline Starting salaries for graduates from the University & $48 \%$ & $\begin{array}{l}\text { Indirect: Improved access to information } \\
\text { salary rates of alumni }\end{array}$ \\
\hline Campus has modern facilities & $76 \%$ & \\
\hline Social and cultural life at University & $76 \%$ & \\
\hline Access to computers and free internet on campus & $74 \%$ & \\
\hline That they would fit in well at the University & $66 \%$ & \\
\hline Campus surroundings (eg beaches, pubs) & $49 \%$ & \\
\hline Sporting and recreation facilities on campus & $47 \%$ & \\
\hline That it's a large campus & $20 \%$ & \\
\hline How easy it is to get to the University from home & $70 \%$ & \\
\hline Location of University in metropolitan area/city & $66 \%$ & \\
\hline Ability to live at family home while studying & $59 \%$ & \\
\hline Availability to accommodation/residences on campus & $40 \%$ & $\begin{array}{l}\text { Indirect: Process optimisation can help } \\
\text { students find on campus accommodation }\end{array}$ \\
\hline Availability of rental housing off campus & $35 \%$ & $\begin{array}{l}\text { Indirect: Process optimisation can help } \\
\text { students find off campus accommodation }\end{array}$ \\
\hline
\end{tabular}

Regarding Government "choices": there is a direct link to one aspect of Enterprise System benefits in particular: that of access to information. As previously discussed, both the Danish and Australian governments demand complex, detailed, accurate and regular reporting of student numbers. Notably, also, Universities are not just funded on student numbers. They also receive significant funds for research. The Australian government, for example, provided \$Aus2.3 billion for research grants at public Universities in 2010, compared with \$Aus7.6 billion for student places [45]. In addition Universities receive significant research funds from other sources, and, as one Australian Vice Chancellor recently said: "We don't receive any specified, targeted funding for the 40 per cent of an academic’s time that is spent just doing research” [46].

\section{Discussion and conclusion}

University Enterprise Systems have the potential to bring benefits in some areas. However, they differ from the benefits to supermarkets in two main ways. Firstly, almost all the Enterprise Systems benefits for Universities are based on improved access to information, as they depend critically on Government funding. Furthermore, they plan and recruit differently from supermarkets. The emphasis on research, reflected in the priorities of both their government and student "customers" means that they need to recruit staff who can perform this activity, and hence operate under constraints that are not present for supermarkets. This is linked to the University "inventory" of study programmes and courses, as research active staff need to teach these. This requires complex forecasting and planning. By comparison, supermarkets derive significant, direct benefits from process optimisation and integration along the supply chain, and rather less benefits from improved access to information. 
Secondly, most of the benefits from Enterprise Systems are reflected directly in the factors affecting customers' choices of supermarkets. By comparison, very few of the influences on student choices of University are affected by Enterprise System benefits.

Several research and practical questions arise from this study. Compared with supermarkets, Universities depend critically on good accurate information, while depending far less on optimised processes. Universities are often organised along federal lines, in Faculties, for example, which all needing to supply and use similar, central information, may prefer to use different processes. The admissions process for a medical student, for example, may be very different from that for an IT student. This has implications for research into appropriate Enterprise Systems designs in organisations with integrated information needs but federal processes. Furthermore, project management plans need to take account of multiple stakeholder needs, and, sometimes, possibly, optimise a number of processes rather than aim for the one "best practice process" which would normally form part of Enterprise System project plans.

There are many, interrelated factors regarding why Universities survive in a competitive market. Few of these are related to Enterprise System benefits: a scenario is quite possible where one University with an excellent Enterprise System would have more problems surviving than one with poor systems, but, say, key researchers and a history of excellent relationships with graduate employers. This leads to a questioning of the model, critical to Enterprise project management, of high level stakeholder support, and of prioritising the investment in Enterprise systems. Research could be conducted into models for implementing large, complex systems in environments where the benefits of those systems are not critical to the organisations survival.

\section{References}

* $\quad$ Danish University website - source withheld to maintain anonymity

** $\quad$ Australian University website - source withheld to maintain anonymity

1. $\quad$ Seddon, P.B., C. Calvert, and S. Yang, A Multi-Project Model of Key Factors Affecting Organizational Benefits from Enterprise Systems. MIS Quarterly, 2010. 34(2): p. 305 - 328.

2. Berente, N., U. Gal, and Y. Yoo, Dressage, control and enterprise systems: the case of NASA's Full Cost Initiative. European Journal of Information Systems, 2010. 19: p. 21-34.

3. $\quad$ Ciborra, C., From Control to Drift: The Dynamics of Corporate Information Infrastructures. 2000: Oxford University Press.

4. $\quad$ Ciborra, C., The Labyrinths of Information: Challenging the Wisdom of Systems. 2002: Oxford University Press.

5. Davenport, T.H., Putting the Enterprise into the Enterprise System. Harvard Business Review, 1998. 76(4): p. 121131.

6. Dechow, N. and J. Mouritsen, Enterprise Resource Planning Systems, Management Control and the quest for integration. Accounting, Organisations and Society, 2005. 30: p. 691-733.

7. Markus, M.L., et al., Learning from adopters' experiences with ERP: problems encountered and success achieved. Journal of Information Technology, 2000. 15: p. 245-265.

8. Quattrone, P. and T. Hopper, What does organizational change mean? Speculations on a taken for granted category. Management Accounting Research, 2001. 12: p. 403-435.

9. Quattrone, P. and T. Hopper, What is IT? SAP, accounting and visibility in a multinational organisation. Information and Organization, 2006. 16: p. 212 - 250.

10. Ross, J.W., P. Weill, and D. Robertson, Enterprise Architecture as Strategy: Creating a Foundation for Business Execution. 2006: Harvard Business School Press.

11. vom Brocke, J. and M. Rosemann, eds. Handbook on Business Process Management. International Handbooks on Information Systems, ed. Springer. 2011.

12. Harmon, P., Business Process Change: A Guide for BUsiness Managers and BPM and Six Sigma Professionals: Second Edition. 2007: Morgan Kaufman.

13. Barney, J.B., Firm resources and sustained competitive advantage. Journal of Management 1991. 17(1): p. 99120.

14. Grant, R.M., The resource-based theory of competitive advantage: Implications for strategy formulation. California Management Review, 1991. 33(3): p. 114-153.

15. Mata, F.J., W. Fuerst, and J.B. Barney, Information Technology and Sustained Competitive Advantage: A Resource-Based Analysis. MIS Quarterly, 1995: p. 487-505.

16. Porter, M.E., Competitive Advantage: Creating and Sustaining Superior Performance (with 1998 introduction). 1985, 1998, New York: The Free Press.

17. Treacy, M. and F. Wiersema, The Discipline of Market Leaders. 1995, New York: Basic Books.

18. Callista. Callista: Better Student Management. 2011 [cited 2011 9th June]; Available from: http://www4.callista.com.au/display/website/Home. 
19. Ernst, D.J., Is there life after ERP and is it better than before?, in EDUCAUSE. 2007: Melbourne, Australia.

20. Oracle. PeopleSoft Campus Solutions 9.0 Feature Pack 3. 2011 [cited 2011 16th June]; Available from: http://www.oracle.com/us/products/applications/peoplesoft-enterprise/campus-solutions/campus-solutions-9feature-pack-3-166151.html.

21. SITS/Tribal. SITS:Vision. 2011 [cited 2011 9th June]; Available from: http://www.tribalgroup.com/education/ITsolutions/ManagementIS/Pages/SITSVision.aspx/Pages/default.aspx.

22. Swartz, D. and K. Orgill, Higher Education ERP: Lessons Learned, in EDUCAUSE. 2000: Nashville.

23. TechnologyOne, TechnologyOne's new gen student management solution goes live in time for mid-year enrolments 2011.

24. Competition_Commission, Supermarkets: A report on the supply of groceries from multiple stores in the United Kingdom. 2000.

25. DEEWR and Roy_Morgan_Research, Year 12 Student Choices, E.a.W.R. Australian Government: Department of Education, Editor. 2009: Sydney. p. 1-213.

26. Shanks, G., P.B. Seddon, and L. Willcock, eds. Second-wave enterprise resource planning systems: implementing for effectiveness 2003, Cambridge University Press.

27. Porter, M.E., Competitive Advantage. 1980, New York: Free Press.

28. Kearns, G.S. and A.L. Lederer, A resource-based view of strategic IT alignment: How knowledge sharing creates competitive advantage. Decision Sciences, 2003. 34(1): p. 1-29.

29. Peppard, J. and A. Rylander, From Value Chain to Value Network: Insights from Mobile Operators. European Management Journal, 2006. 24(2).

30. $\quad$ Porter, M.E., Strategy and the Internet. Harvard Business Review, 2001: p. 62-78.

31. Jarzabkowski, P., Strategy as Practice: an activity-based approach. Strategy Series. 2005, London, : SAGE.

32. Baumber, K. and J. Mullarvey, From MAC to CASMAC and beyond. Perspectives: Policy and Practice in Higher Education, 2000. 4(4).

33. McDonough, W.R., The Management and Administrative Computing (MAC) Initiative. Higher Education Management, 1992. 4(3): p. 284-92.

34. CASMAC, Core Australian specification for management and administrative computing (CASMAC) version 2. 1991.

35. Jillbert, J., D. Rosmal, and M. Carreon, Integrated systems: management approaches to acquiring them in Australian Universities, in ITIRA. 2003.

36. Vitale, M.R., Recovering from Software Development. Educause, 2000.

37. Berglund, S., Consortia - the new way insititutions work together or a new approach to old problems in institutional collaboration, in 16th Annual EAIR Forum. 1994: Amsterdam, Holland.

38. LADOK. The LADOK system. 2011 [cited 2011 9th June ]; Available from: www.ladok.se.

39. ISACA, Security, Audit and Control Features SAP ERP 3rd Edition. Technical and Risk Management Reference Series, ed. ISACA. 2009.

40. UAC. Universities Admissions Centre. 2011 [cited 2011 9th June]; Available from: www.uac.edu.au.

41. Walters, C., International students - returning their investment, in Going Global 2011. 2011: Hong Kong.

42. Schmidt, E.K., K. Langberg, and K. Aaagard, Funding Systems and their effects on Higher Education Systems: Country Study Denmark, OECD, Editor. 2006, The Danish Centre for Studies in Research and Research Policy, University of Aarhus.

43. Emmanuel, I. and G. Reekie, FINANCIAL MANAGEMENT AND GOVERNANCE IN HEIS: AUSTRALIA, in OECD IMHE HEFCE PROJECT ON INTERNATIONAL COMPARATIVE HIGHER EDUCATION FINANCIAL MANAGEMENT AND GOVERNANCE, HEFCE-OECD/IMHD, Editor. 2004, Commonwealth Department of Education, Science and Training: Canberra.

44. DEEWR. Budget 2009-10: Student demand to drive university funding. 2009 [cited 2011 9th June]; Available from: http://www.deewr.gov.au/ministers/gillard/media/releases/pages/article_090512_182600.aspx.

45. Australian_Government, The Higher Education Base Funding Review: Background paper. 2010.

46. Hare, J. and B. Lane, Research spending consumes growing proportion of university funding, in The Australian 2011. p. p 23. 